\title{
The Commons' two committee systems and scrutiny of government policy-making
}

In addition to their floor debates, a crucial role of legislatures is to scrutinise government law-making and policy implementation. The House of Commons looks at legislation via bill committees, and its select committees cover each of the Whitehall departments to scrutinise implementation. Patrick Dunleavy and the Democratic Audit team consider how well current processes maintain parliamentary knowledge and scrutiny of the central state in the UK and England.

\section{What does democracy require for how the national legislature monitors, understands, publicises and questions the policies that national government develops?}

The elected legislature should normally maintain full public control of government services and state operations, ensuring public and parliamentary accountability through conditionally supporting the government, and articulating reasoned opposition, via its proceedings.

The House of Commons should be a critically important focus of national political debate, articulating 'public opinion' in ways that provide useful guidance to the government in making specific and often complex policy choices.

Individually and collectively legislators should seek to uncover and publicise issues of public concern and citizens' grievances, giving effective representation both to majority and minority views, and showing a consensus regard for the public interest.

In the preparation of new laws, the legislature should supervise government consultations and help to ensure effective pre-legislative scrutiny.

In considering legislation, Parliament should undertake close scrutiny in a climate of effective deliberation, seeking to identify and maximise a national consensus where feasible.

Legislators should regularly and influentially scrutinise the current implementation of policies, and audit the efficiency and effectiveness of government services and policy delivery. 
The House of Commons is one of the oldest and foremost legislatures in the world - yet in the past it was also a byword amongst political scientists for weak legislative control of government. Some recent political science work has painted a more active picture of MPs' influence. Beyond the floor debates in the main Commons chamber (see Chapter 4.1) - and the rowdy weekly showcase of Prime Minister's Question Time - the House of Commons also does a lot of detailed work in committees holding the government to account. (The Lords have their own, smaller and much less influential group of select committees, but our focus in this chapter is solely on the work of the democratically elected Commons.)

\section{Recent developments}

The House of Commons' select committee system shadows the work of every civil service department and has grown in influence over time. In the past, the issue of reconstituting committees after a general election has sometimes been delayed, and until 2010 the party whips in the Commons 'fixed' who would chair which committee. Following the 'Wright' reforms made after 2009, however, committee chairs can be elected by MPs, if there are multiple candidates. Figure 1 shows that only nine contests were held for the 26 chair positions in July 2017. However, this low number reflects the fact that many influential and well-liked chairs continued unchallenged from the 2015-17 parliament.

Figure 1: Key characteristics of the 26 select committee chairs in July 2017

\begin{tabular}{|l|r|l|l|l|l|l|l|}
\hline Party & No. & Experience & No. & $\begin{array}{l}\text { Type of } \\
\text { committee }\end{array}$ & No. & $\begin{array}{l}\text { Competition } \\
\text { for post }\end{array}$ & No. \\
\hline Conservative & 14 & Backbench & 10 & Departmental & 18 & One candidate & 17 \\
\hline Labour & 10 & $\begin{array}{l}\text { Cabinet/ } \\
\text { Shadow } \\
\text { Cabinet }\end{array}$ & 9 & Parliamentary & 5 & Election held & 9 \\
\hline $\begin{array}{l}\text { Liberal } \\
\text { Democrat }\end{array}$ & 1 & Minister & 4 & Cross-Cutting & 3 & \\
\hline $\begin{array}{l}\text { Scottish } \\
\text { National Party }\end{array}$ & 1 & $\begin{array}{l}\text { Junior } \\
\text { minister }\end{array}$ & 3 & & & & \\
\hline
\end{tabular}

Source: From data in HC Speaker, 2017

Figure 1 also shows that half of the chairs have ministerial experience, with nine having earlier been Cabinet ministers or Shadow Cabinet spokespersons - showing the increasing salience of these chairing roles (which also attract a salary addition for the MPs involved). There are 18 single-department committees, five that handle internal parliamentary issues, and three cross-cutting committees, of which the Public Accounts Committee (PAC) is best known. The distribution of chairs broadly follows the proportion of MPs belonging to each party. After the 2016 EU referendum the Department for Exiting the EU Committee, chaired by Labour's Hilary Benn, was set up to scrutinise the work of the new DExEU, and similarly the International Trade Committee supervises the new Whitehall department DIT. 


\section{Strengths, Weaknesses, Opportunities, Threats (SWOT) analysis}

\section{Current strengths}

The select committee system now provides one committee scrutinising each Whitehall department's executive actions and implementation processes in detail. Select committee members build up worthwhile expertise in that area and a more effective 'corporate' spirit than in the past. Attendance at committee sessions has increased and there is more of a premium on effective engagement by members.

Select committee chairs are now paid a worthwhile salary increment and attract a good deal of media attention. So this role has grown in salience. It increasingly attracts serious ex-ministers and genuinely expert and less-partisan backbenchers, who can command regular engagement from their committee members.

Since mid-2007 select committees have had the capability to review major ministerial appointments of people to head quasi-government agencies. These pre-appointment hearings now help shape how ministers and top officials make these appointments. Out of a set of 59 hearings to 2017, appointments have divided committees or been rejected 13 times. Some very serious government jobs have been involved. MPs on the Education Committee initially rejected the government's proposed head of Ofsted (which monitors schools' quality) after a lacklustre performance at their hearing. And a candidate for Bank of England Deputy Governor resigned in 2017 after the Treasury Select Committee criticised incomplete answers that she had given them.

\section{Current weaknesses}

Select committees only work effectively when they operate in a bipartisan manner, with MPs from different sides of the committee endorsing the same report. Creating this 'corporate' spirit is difficult and biases the topics that committee chairs investigate, because they are anxious to secure wide agreement. As a result, critical issues dividing the parties may not be examined as being 'too difficult'. Sometimes committees will take on an issue wanted by party A, but only so long party $B$ also gets its favourite issue tackled. These cases rarely work well.

Both departmental and bill committees mostly operate by calling 'witnesses' to give evidence, and taking written evidence from relevant or involved bodies. This is a weak and old-fashioned form of information gathering. It produces a lot of claim and counter-claim that committees do not have the staff or expertise to critically or objectively assess - except in a vague, judgement-of-plausibility manner.

There is strong evidence of a past lack of diversity in who is invited to give evidence (see below), partly reflecting biases in who sits on committees. Women MPs have been severely under-represented on some committees, especially Defence and Foreign Affairs whose members were $93 \%$ male from 1979 to 2017. Women MPs are most prominent on the health and education committees. 


\section{Current strengths}

The support staff for chairs and committee members has increased somewhat. And in response to criticisms of a lack of witness diversity, select committees staff and chairs have recently been more proactive about soliciting evidence from people who might not normally volunteer as witnesses.
The Public Accounts Committee (PAC) benefits from research by the National Audit Office's 800 professional staff in 60 'value for money' (VFM) reports per year. (NAO is the leading parliamentary agency providing an independent check for MPs that monies voted to the government were spent for the correct purposes and in an effective manner.) PAC hearings and final reports regularly attract media attention in addition to the NAO reports themselves.

The PAC Chair is always a senior opposition figure, and plays a significant role in giving some 'parliamentary' overview of secret spending and defence areas, signing off on some key mega-projects for instance.

\section{Current weaknesses}

Select committees' powers to compel witnesses to appear and to tell the truth seem weak and undefined. Senior civil servants have to appear before select committees, but ministers may refuse. The committees can invite outsiders to appear, and they might be in contempt of Parliament if they fail to show up. Witnesses have to answer questions but can claim not to know or have information with impunity. Some corporate sector witnesses have made plain their unwillingness to be frank, without much come-back.

Many PAC reports currently concern only single-department subjects, and could more helpfully be processed by the relevant departmental select committees. These other committees could also benefit greatly from gaining access to the NAO staff and expertise to boost their information-generating capabilities. But at present PAC 'exclusivism' has prevented most select committees from gaining any NAO assistance, except for a few cases.

Funnelling all the post hoc financial scrutiny of public spending through only one committee (PAC) wastes much of the work of the National Audit Office (NAO) in scrutinising the civil service. PAC's agenda is a crammed one, so that time devoted to cross-Whitehall issues is regularly squeezed by the pressure of single department reports, sometimes quite minor in scale. PAC members are necessarily generalists in terms of processing a random stream of reports across different departments, although they do develop experience of Whitehall spending and control processes. The NAO also produces around 10-15 VFM reports per year that are never reviewed by any parliamentary committee because of capacity limits in the PAC. 


\section{Current strengths}

Some political scientists (like Louise Thompson) have called for a re-evaluation of the dominant views of bill committees (also called legislative committees). She found that around three-fifths of bill committee members have relevant specialist expertise and she argues that some committee sessions achieve impressive levels of deliberative quality.
'Revisionists' have also defended bill committees as showing up the 'viscosity' of different measures - they alert ministers about where changes are needed, even if the changes involved are always those proposed by ministers.

Parliament has no separate procedures for considering major government projects in technical or expert consideration ways before money is spent on them contributing to what critics see as the prevalence of 'policy disasters' in the UK.

\section{Current weaknesses}

Many critics see scrutiny of legislation via partisan whipped bill committees (with many inexpert MPs just voting a party line) as always ritualistic, ineffective and normally of very little value. Government whips can completely dominate proceedings, with the committee majority accepting only government amendments. Many (two or more out of five) members are still just 'cannon fodder' attendees, primed to vote the party line, whatever problems emerge in discussion.

The separation of bill committees from select committees is unhelpful and reduces the ability to have legislation reviewed by genuinely expert MPs. The deliberative quality of legislative committee sessions has also been seen as low, reaching a nadir when the timetabling for bills gets under pressure (as it often does).

Bill committees have been widely seen as ineffective in securing effective scrutiny. Only half of $1 \%$ of accepted amendments in and after the committee stage are from the opposition. Even Thompson finds that the vast bulk (84\%) of changes made are still government ones. (11\% are also changes to regulations or guidance for bills made by departments.)

All NAO and PAC scrutiny activities occur 'after the fact', and so are limited to a post hoc audit role. The NAO claims to save £9 for every £1 that it spends, but PAC plays no prospective or policy-warning role on decisions. Small amounts of NAO advice go to other select committees, for example, checking the economic growth estimates included in the Chancellor's annual public spending statements. 


\section{Future opportunities \\ The return of a hung parliament in June 2017, just two years after the earlier 2010-15 period, may once more encourage MPs to be more assertive towards the executive on more issues - especially those that can command cross-party agreement on improving specific policies - as occurred in 2017-18 over a troubled social welfare reform, Universal Credit.}

Proposals for incremental reforms, such as allowing the NAO to advise departmental select committees more, and for MPs there to discuss more single department VFM studies in their area, could bring worthwhile improvements quickly, increasing the expertise available to select committees.

\section{Future threats}

The Brexit process is likely to involve extensive use of statutory instruments, over which parliamentary surveillance has generally been weak.

Reports on single department and smaller spending issues could be run through other select committees. The PAC could then focus more effectively on cross-departmental, intergovernmental and major spending areas. However, radical proposals such as these, or even their more moderate versions (see opposite), seem unlikely to be adopted, with select committees still locked into obsolescent and high cost ways of calling 'witnesses'.

\section{Bill committees}

During the legislative process, most bills are sent to a committee stage when a group of at least 11 MPs consider the proposed Act, clause-by-clause in detail. Of course, the ministers attending come from the department involved and are matched by the Shadow Cabinet frontbenchers that parallel them, and this brings a certain degree of different expertise to each discussion. But many of the remaining MPs are just those deputed by the party whips to serve on each committee. Each committee handles a varied stream of legislation in which the 'ordinary' members may have little expertise. There are generally six legislative committees operating in tandem.

Critics have historically argued that the committees have no real purpose beyond being a kind of 'mini-me' image of the Commons as whole, always dominated by a government majority and chair. Over $\mathbf{9 9 \%}$ of ministerial amendments moved at the committee or report stages succeed, while the success rate for non-government amendments is below $1 \%$. Opposition amendments almost never succeed, despite the fuss made by some authors about the greater incidence of backbench rebellions. Most MPs vote with the party line almost all the time, in committee as much as on the House floor. Partisan timetabling considerations also shape how 'line by line' any scrutiny is, with guillotines often invoked. And Berry notes that 'sometimes whole sections of bills pass through committees without scrutiny'. 
Some recent authors have argued for a more optimistic picture. Russell and Cowley reported on a systematic examination of over 4,360 amendments on six bills, which at one level replicated the picture above. However:

'closer examination found that nearly three-quarters of government amendments had little policy substance - being purely technical, clarificatory, or "consequential" on other amendments. Of those government amendments with substance that actually changed any of the bills, over $60 \%$ - 117 in total - were traceable to influence from nongovernment parliamentarians, usually through prior amendments withdrawn when ministers promised to reconsider. In most cases, there was no [government] defeat involved, but some changes were substantial'.

Similarly Thompson's 2015 study argued that:

'bill committees are the perfect conduit for changes to government bills. They enable ministers to effectively be lobbied by MPs. They are both the breeding ground for amendments to legislation and a platform for allowing policy issues which have already been aired by MPs through other parliamentary tools to be tagged on to a bill, making policy change more likely.' (p.89).

These arguments suggest that the committee and report stages of legislation can increase the 'viscosity' of different measures, pointing ministers and officials towards fixing the most egregiously damaging of their initial provisions. However, this remains an exceptionally modest role, and one that falls well below the rationale of careful deliberative debate and consideration that other legislatures in Europe can claim.

\section{The increasing salience of select committees}

Much of government uses executive capabilities and administrative discretion to deliver services, make regulations or undertake interventions in particular ways. From its foundation in 1979, the select committee system has provided an ever more influential mechanism for 'shadowing' each department and bringing legislators' views to bear. Having MPs elect committee chairs, and paying them extra salary, has especially helped them to evolve into better independent forces for policy scrutiny. Their records of influential hearings and reports have grown their media and public profiles. Especially under the coalition government (2010-15), select committees became important venues for discussing controversial issues. Figure 2 show that press mentions of Commons committees in the UK press broadly tripled from 2008 to 2012 in terms of both total press mentions and the average (mean) for committee mentions. 
Figure 2: Increase in press coverage of House of Commons Committees, 2008-12

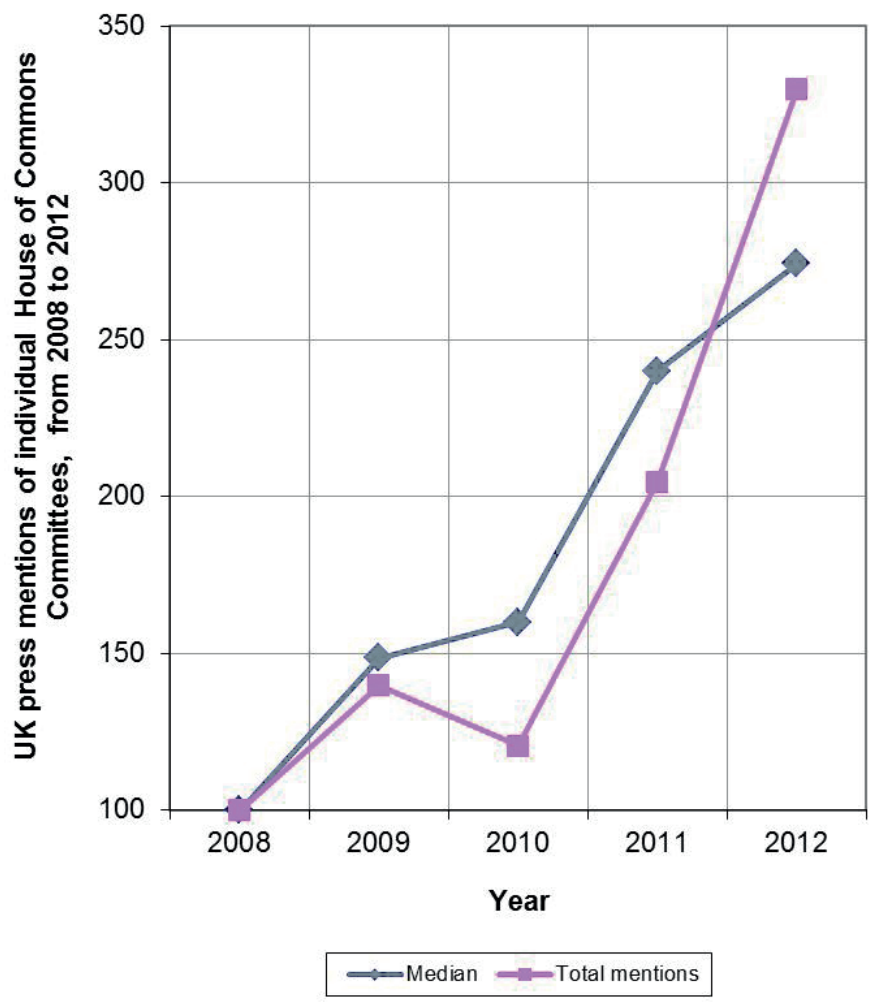

Source: Dunleavy and Muir, 2013. Analysis of Lexis-Nexis press database.

Figure 3 provides a detailed view of which committees became more salient in this period, and which did not. The pink rows show that much of the total increase in mentions in this period took place in four exceptionally prominent committees:

The Public Accounts Committee (see the SWOT analysis above). At this time it had a dynamic new chair in Margaret Hodge MP.

The Home Affairs Select Committee, already the second-most important committee in 2008. Its press mentions increased sharply in 2011 and 2013, following the summer riots in London and the Committee's inquiries into them.

The Treasury Select Committee was another already important committee in 2008 under the Conservative chair Andrew Tyrie. In 2017, the former Tory Cabinet minister Nicky Morgan won election as chair, quickly assuming a pro-active approach.

The Culture, Media and Sport committee. Its prominence at this period grew greatly during the phone-hacking scandal over media behaviour. Both Rupert and James Murdoch were called to give evidence on the scandal in 2011, attracting global media coverage. This interest continued during the subsequent Leveson Inquiry process. 
Figure 3: Trends in the UK press mentions of Commons' select committees, 2008-12

\begin{tabular}{|c|c|c|c|c|c|}
\hline Committee & 2008 & 2009 & 2010 & 2011 & 2012 \\
\hline Home Affairs & 295 & 405 & 302 & 989 & 2033 \\
\hline Public Accounts & 557 & 644 & 639 & 813 & 1956 \\
\hline Treasury & 213 & 418 & 277 & 308 & 530 \\
\hline Culture, Media and Sport & 49 & 85 & 102 & 573 & 476 \\
\hline Transport & 135 & 113 & 90 & 186 & 229 \\
\hline Public Administration & 58 & 90 & 80 & 81 & 200 \\
\hline Energy and Climate Change & 55 & 58 & 86 & 101 & 148 \\
\hline International Development & 27 & 15 & 13 & 42 & 112 \\
\hline Standards and Privileges & 143 & 333 & 181 & 98 & 94 \\
\hline Scottish Affairs & 17 & 48 & 24 & 37 & 73 \\
\hline Health & 30 & 36 & 42 & 54 & 70 \\
\hline Environmental Audit & 83 & 54 & 50 & 79 & 62 \\
\hline European Scrutiny & 16 & 15 & 40 & 68 & 58 \\
\hline Defence & 81 & 94 & 73 & 108 & 56 \\
\hline Education & 10 & 7 & 20 & 39 & 55 \\
\hline Business, Innovation \& Skills & 0 & 10 & 49 & 46 & 54 \\
\hline Work and Pensions & 17 & 27 & 18 & 58 & 42 \\
\hline Backbench Business & 0 & 3 & 28 & 121 & 41 \\
\hline Foreign Affairs & 44 & 65 & 40 & 42 & 36 \\
\hline Commons Liaison & 13 & 44 & 28 & 17 & 34 \\
\hline Justice & 25 & 30 & 32 & 31 & 32 \\
\hline Procedure & 9 & 18 & 24 & 30 & 28 \\
\hline Communities \& Local Government & 25 & 33 & 16 & 18 & 24 \\
\hline Political \& Constitutional Reform & & 2 & 20 & 27 & 21 \\
\hline Environment, Food \& Rural Affairs & 13 & 11 & 9 & 8 & 18 \\
\hline Northern Ireland Affairs & 14 & 9 & 22 & 12 & 9 \\
\hline Welsh Affairs & 5 & 1 & 4 & 5 & 4 \\
\hline Finance and Services & 0 & 1 & 1 & 0 & 2 \\
\hline Administration & 0 & 0 & 0 & 1 & 1 \\
\hline Members' Expenses & 0 & 0 & 0 & 3 & 1 \\
\hline Armed Forces Bill & 0 & 0 & 0 & 3 & 0 \\
\hline Commons Privileges & 1 & 0 & 4 & 0 & 0 \\
\hline Regulatory Reform & 18 & 5 & 0 & 2 & 0 \\
\hline
\end{tabular}

Source: Dunleavy and Muir, 2013. Analysis of Lexis-Nexis press database.

Notes: We searched across years in a standard grid, so committees may not exist in all years covered. 
The green rows in Figure 3 also show that seven other Commons committees enjoyed a consistent growth of press coverage in this period. Overall, 14 committees more than doubled their press mentions between 2008 and 2012. A further four saw smaller increases, while seven committees received less coverage.

More recently select committees have moved into other controversial areas, with the Work and Pensions and the Business committees both summoning Sir Philip Green to attend a hearing in June 2016 to answer questions over the collapse of BHS with hundreds of millions of pounds apparently missing from the pensions fund.

Yet were select committees just more attractive 'talking shops' for the media? Or have their deliberations and especially their recommendations had substantial effects on policy? The grounds for thinking they have start with their selection of issues to cover, which has tended to become topical and substantial over time.

One innovative study collated many thousands of recommendations to government made by seven select committees over a long period, and then set out to chart how many of these were recommended, and how many were subsequently acted upon. Figure 4 shows the key results for implementation of a large set of over 1,330 recommendations that could be tracked. The authors concluded with a strikingly benign assessment: 'Numerous committee recommendations are implemented by government, including many for major policy change'.

Figure 4: How recommendations from seven select committees were implemented by the government, or not (1997- 2010)

$\%$ of total recommendations implemented

\begin{tabular}{|l|r|r|r|r|r|r|}
\hline Scale of change in & Fully & Partially & $\begin{array}{l}\text { Limited } \\
\text { attempts }\end{array}$ & $\begin{array}{l}\text { Unclear if } \\
\text { acted on } \\
\text { or not }\end{array}$ & $\begin{array}{l}\text { Clearly } \\
\text { not } \\
\text { acted } \\
\text { upon }\end{array}$ & $\begin{array}{l}\text { Row } \\
\text { totals }\end{array}$ \\
\hline No or small change & 15 & 8 & 6 & 5 & 3 & 39 \\
\hline Medium change & 8 & 10 & 10 & 13 & 12 & 52 \\
\hline Large change & 1 & 1 & 1 & 1 & 3 & 6 \\
\hline Scale unclear & 1 & 0 & 0 & 0 & 1 & 2 \\
\hline All recommendations & 25 & 19 & 18 & 19 & 18 & $100 \%$ \\
\hline
\end{tabular}

Source: Computed from Benton and Russell, 2013, Table 1. The committees covered were those for BIS, Defence, Foreign Affairs, Health, Home Affairs, Public Administration (PAC) and Treasury. The period covered was the Blair and Brown governments. 
However, Figure 4 shows that this is a highly 'stretched' interpretation of the actual findings. The numbers in orange cells show that one in five (20\%) of the trackable committee recommendations were both 'medium' or 'large scale' in their impacts, and also implemented by government. But one in six recommendations (15\%) (in the green shaded cells) were at the same scale and were clearly rejected by government (while in a further one in seven cases implementation was unclear). Large-scale changes accepted by minister in fact formed only $2 \%$ of recommendations (the dark orange cells), whereas those rejected at this scale were $3 \%$.

Of course, our interpretation here excludes the top row in Figure 4 covering 'no change' or small change recommendations from committees. MPs and Commons officials will freely admit that there is an accepted art of writing 'chaff' committee recommendations, which suggest to ministers or officials that they should do something small that they already want to do anyway. This tactic allows the committee to look friendly and 'on the same page' as the executive. And it fosters government MPs supporting reports that make criticisms elsewhere, since ministers can agree to the easy bits. So although the top row in Figure 4 shows another 23 to $29 \%$ of minor recommendations being implemented (versus only $3 \%$ not acted on), these cases probably are 'chaff', and so ought to be set aside.

Nevertheless, although committees' hit rate for acceptance and implementation of recommendation is perhaps far less than some over-enthusiastic accounts suggest, it is still a pretty creditable record. Select committees remain one of only two areas where the Commons is clearly contributing to detailed policy-making.

\section{Who does Parliament ask for their views?}

Because Westminster relies so heavily on calling witnesses as a way of bring in outside knowledge to the scrutiny of legislation and of policy implementation it matters a lot who submits evidence. Academic research shown in Figure 5 found that most submissions came from interest groups, individuals and private companies - and that surprisingly only one in 16 submissions came from 'experts' and slightly less from think tanks.

However, witnesses who give oral evidence in person before committees, and hence can be questioned by committee members, are generally those judged more important or more knowledgeable by chairs (and their clerks). A study of all witnesses who gave evidence to select committees only in the 2013-14 session of parliament showed that civil servants and public-sector agencies were the biggest group (see Figure 6). A further one in eight witnesses were ministers or parliamentarians, so that almost half of those appearing were from Whitehall and surrounds, as one might expect. The civil society sources for witnesses were NGOs, think tanks and interest groups, and then private sector companies and trade associations, with academics from higher education third. 
Figure 5: The main actors who gave evidence to Westminster legislative and select committee in the period 2010-11

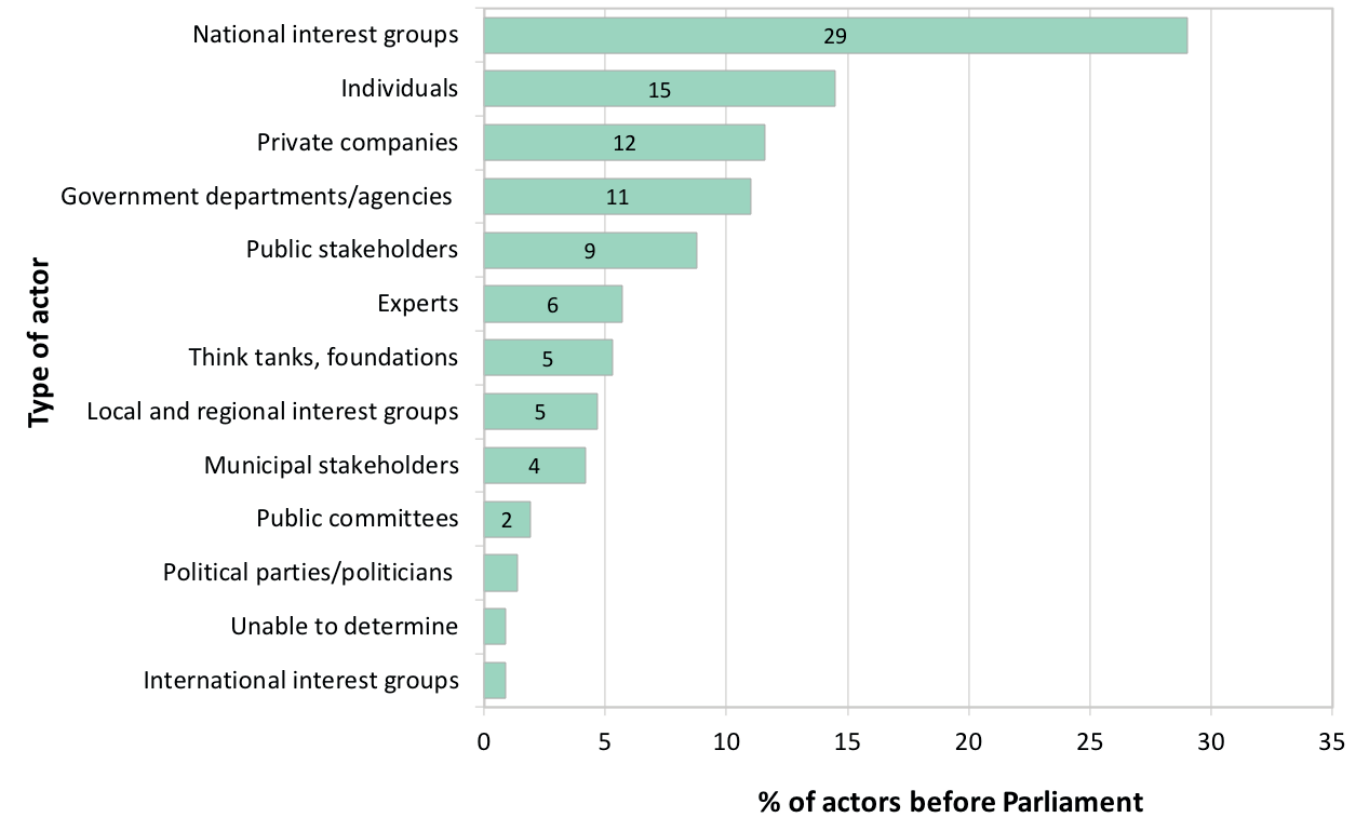

Source: Helboe et al (2015), Table 2.

Notes: Data on oral and written evidence collected from the UK Parliament's website, August 1, 2010 to July 31, 2011. Percentages of $N=8431$.

Figure 6: The organisational affiliations of oral witnesses to all select committees, 2013-14 session

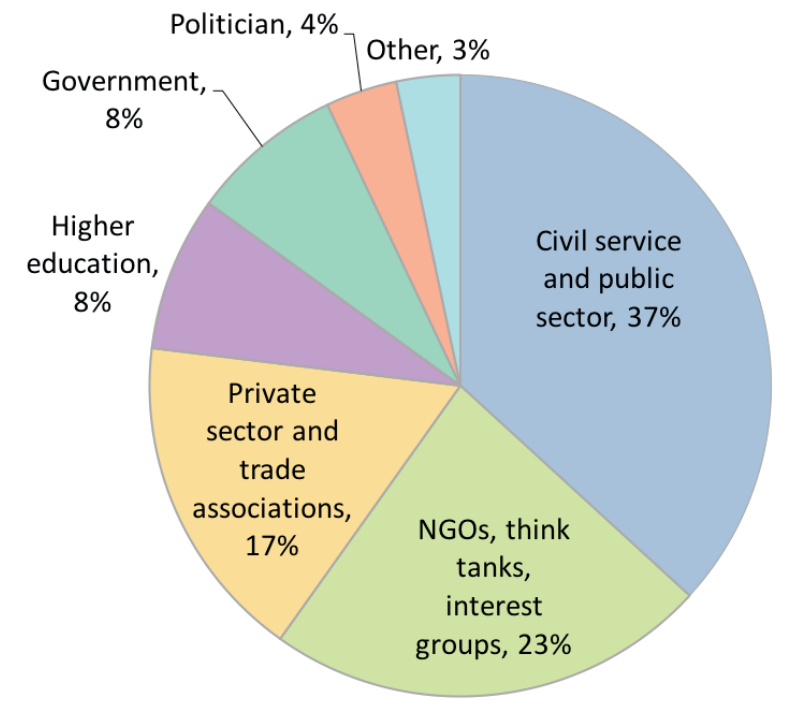

Source: Re-calculated from Geddes, 2018 Notes: We have moved trade associations into the 'private sector' category here, and out of the 'NGOs and think tanks' category. 


\section{Figure 7: The organisational affiliations of 120 expert witnesses to select committees, in two months, autumn 2013}

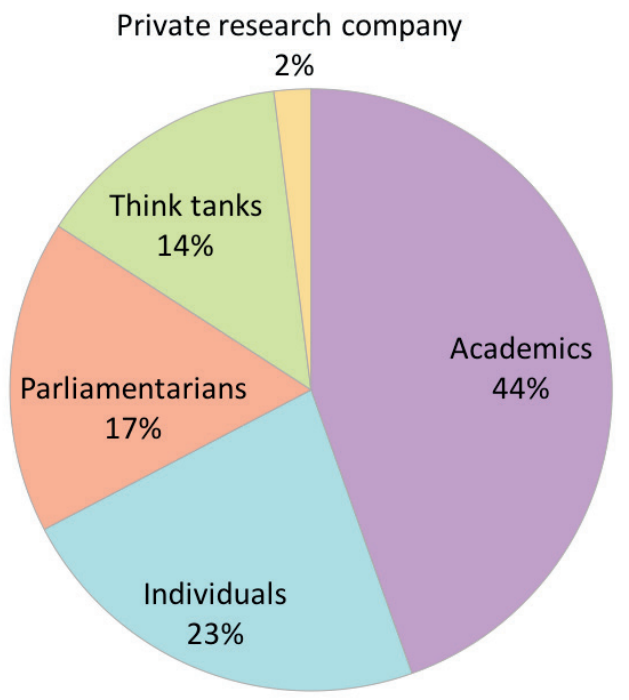

Source: Berry and Kippin, 2014, Figure 4.

Notes: Data covers 120 expert witnesses giving oral evidence to select committees in October-November 2013.

Percentages of $N=541$.

A broadly similar picture is also given by a Democratic Audit study of nearly 600 witnesses who appeared before 153 hearings in autumn 2013. That analysis also looked in depth at the make-up of 120 'expert' witnesses, whose role may be especially helpful for MPs in uncovering well-founded (rather than partisan) evidence. Figure 7 shows that academics were exceptionally prominent (accounting for nearly half of all expert witnesses in person), plus think tanks and trade associations.

A more disturbing finding of both the 2013-14 studies was that in this period around $75 \%$ of witnesses going to committees were men. Some committees like PAC heard from nine men for every woman appearing. Following on from their research in 2014, the Democratic Audit staff involved met with committee clerks, and Parliament later took some remedial actions to seek greater diversity amongst witnesses.

\section{Legislative supervision of UK government spending}

In international terms the UK has a strong system of post hoc scrutiny of government spending achieved by the Public Accounts Committee (PAC), acting on the reports of the independent National Audit Office, the UK's 'supreme audit institution' (or SAI). The NAO is perhaps the second most powerful SAI in the liberal democratic world (after the Government Accountability Office in the USA). With a constant flow of high-quality reports to consider, the PAC is a powerful committee, and is always chaired by a leading opposition MP, usually with past ministerial experience. For permanent secretaries attending PAC hearings is a stressful experience requiring a lot of preparation.

Yet it is easy to exaggerate the PAC/NAO influence. In a recent five-year period NAO staff accounted for one-third of witnesses to the PAC, and HM Treasury personnel for 
another $30 \%$. Only seven ministerial departments or major agencies had more than four witnesses a year (Health, Defence, Defra, HMRC, Education, the Home Office and DWP), and another six had over one. Eight departments had one or none per year. In this period, the NAO issued 40 VFM studies that tackled cross-government issues (like digital change in government services, or environmental issues). But the PAC held hearings on only half of these (see Figure 13 in this source). MPs preferred to devote their time to the more easily media-understandable (and more frequently scandalous) reports on single departments. Just officially detailing already well-known cost over-runs and obvious mistakes made by Whitehall (known by senior civil servants as 'bayoneting the wounded') has typically earned the PAC chair more headlines than engaging with more difficult task of fostering sustainable improvements in policy delivery systems.

More generally MPs' stress on ex post scrutiny reflects the fact that they have almost no ex ante influence over budgeting in the UK. Very strong party discipline explains some of this, but a lot stems from restrictions in the House of Commons standing orders. These prohibit any ordinary MP from proposing any amendment to adding even £1 extra on to public spending, unless they can provide the Commons clerks with a certificate signed by a minister - which of course, is never supplied. This blanket ban has spread from the UK to other Westminster system countries and to France and Ireland. It largely explains why Joachim Wehner's comparative index assigns the UK fifth to bottom place in a league table of legislatures' influence over public spending across 30 liberal democracies.

\section{Conclusions}

Where once Parliament lurked almost completely impotently on the sidelines of policymaking, recent research has 'talked up' MPs' collective influence, with some justification in recent hung parliaments. Yet the Commons is still far from having the 'full spectrum' policy influence, genuine deliberation or decisive voice that democratic criteria suggest are needed. Party loyalties greatly inhibit public criticisms and undermine evidence-based reasoning about policies. Consideration of budgets before money gets spent is largely a joke. And legacy procedural practices, plus MPs' traditionalist attachment to inefficient and ineffective ways of working (like the witness system for select committees, instead of developing proper investigative staffs), have limited the legislature's role, despite some positive recent developments.

Patrick Dunleavy is Professor of Political Science and Public Policy at the LSE and coDirector of Democratic Audit there. He is also Centenary Professor in the Institute for Governance and Policy Analysis (IGPA), University of Canberra. 